\title{
Composition and storage of pear cultivars from Nagykanizsa
}

\author{
Tóth-Markus, M. ${ }^{1}$, Bánáti, D. ${ }^{1}$, Adányi, N.1, Boross, F. ${ }^{1}$, Konrád-Németh, C. ${ }^{2}$, Szabó, Z., ${ }^{3}$ \\ Soltész, M. ${ }^{4}$ \& Nyéki, J. ${ }^{3}$ \\ ${ }^{1}$ Central Food Research Institute, Hungary, H-1022 Budapest, Herman Ottó Street 15 \\ tel.: +3613558838 e-mail: m.toth@cfri.hu \\ ${ }^{2}$ Gyümölcskert cPlc Hungary, H-8900 Nagykanizsa, Csengery street 90 \\ ${ }^{3}$ University of Debrecen Centre for Agricultural and Applied Economic Sciences, \\ H-4032 Debrecen, Böszörményi út 138., Hungary \\ ${ }^{4}$ Collage of Kecskemét, Faculty of Horticulture, H-6000 Kecskemét, Erdei Ferenc tér 1-3.
}

\begin{abstract}
Summary: The composition of five pear varieties ('Abate Fètel', 'Bosc', 'Williams', 'Conference', 'Packham's Triumph') grown in Nagykanizsa was investigated in three consecutive years $(2008,2009,2010)$. A storage experiment was performed in 2008. Four winter pear cultivars were kept in an ULO store for four months and their parameters measured after two and four months. The parameters tested were: size, weight, water soluble solids, titratable acidity, glucose, fructose, sucrose, water soluble pectin, total polyphenols, free radical scavenging capacity, copper and zinc content. The fruits of 'Conference' and 'Bosc' varieties were found to contain the highest sucrose and total sugar content, while 'Abate Fétel' had the lowest sucrose and highest glucose levels among cultivars tested. 'Williams' pear was the most acidic. Brix, total sugar, sucrose and water soluble pectin were decreased during storage. Titratable acidity slightly decreased in fruits of Conference pear. Polyphenols and free radical scavenging capacity did not show a significant change during storage.
\end{abstract}

Keywords: pear, storage, sugar, acid, polyphenol, antioxidant capacity

\section{Introduction}

The market value of pear is determined primarily by size, weight, appearance, consistency and taste. Although many results on fruit sugars, acids and polyphenols in different cultivars has been published, there are few studies on change of composition of pear during storage (Morvai \& MolnárPerl, 1992, Elgar et al., 1997). Data on cultivars grown in our country are mainly available in Hungarian. Our aim was to fill this gap.

According to literature data shown in Table 1 the main sugars of pear are fructose, glucose and sucrose. The values are given for $1 \mathrm{~kg}$ fresh weight.

Hudina and Štampar (2000) determined sugars and acids in 18, European and Asian pear cultivars grown in Slovenia, including all those studied in present paper. Colaric and coworkers $(2006,2007)$ studied sugars, acids and phenolic compounds in 'Williams' and 'Conference' pear. They detected chlorogenic acid, syringic acid, epicatechin, catechin, sinapic and vanillic acid with chlorogenic acid being dominating. Main organic acids are malic and citric, with shikimic and fumaric existing as minor compounds.

Pear needs suitable post-harvest storage to assure a good transportability and distribution. Elgar et al. (1997) investigated fruit from two winter pear cultivars stored for 20 weeks at $-0.5^{\circ} \mathrm{C}$. Titratable acidity of ripened fruit decreased with advanced storage: In case of 'Bosc' the acidity changed from $0.187 \%$ to $0.116 \%$, while polyphenolic compounds showed a temporary increase in the first two weeks, and a slight decrease during two months, depending on temperature. Morvai and Molnár-Perl (1992) reported the growth of acids (including ascorbic), sugars and sorbitol during storage of Bosc pear, but the duration and circumstances are not known.

\section{Materials and methods}

\section{Materials}

'Abate Fètel' was grown in orchard of Gyümölcskert cPlc. at Szepetnek-Bánfapuszta. The area is located $15 \mathrm{~km}$ west from Nagykanizsa, with a loamy brown forest soil. The 7-hectare field, where the 'Abate Fètel' rows are grown, is an intensive pear orchard, equipped with irrigator. It was planted in 1997-98 with a spacing of $4 \times 1.4$, grafted on quince (Cydonia oblonga) rootstock. An affinity trouble is presumed, which seems to be proven by the way and extent of tree dying. The average yield in 2008 was $12.6 \mathrm{~kg} / \mathrm{tree}$. 'Abate Fètel' is characterised with a very weak fertility, thus having a low yield and a large size of fruits.

The other cultivars tested were grown at the Feketesár Orchard of Gyümölcskert cPlc. The area is located $15 \mathrm{~km}$ south from Nagykanizsa, with a non-calcareous, sandy 
Table 1: Sugars, acids and polyphenols in pears

\begin{tabular}{|c|c|c|c|c|c|c|c|c|}
\hline Author, date & Cultivar & $\begin{array}{c}\text { Glucose } \\
(\mathrm{g} / \mathrm{kg})\end{array}$ & $\begin{array}{c}\text { Fructose } \\
(\mathrm{g} / \mathrm{kg})\end{array}$ & $\begin{array}{l}\text { Sucrose } \\
(\mathrm{g} / \mathrm{kg})\end{array}$ & $\begin{array}{l}\text { Citric acid } \\
\quad(\mathrm{g} / \mathrm{kg})\end{array}$ & $\begin{array}{l}\text { Malic acid } \\
(\mathrm{g} / \mathrm{kg})\end{array}$ & $\begin{array}{c}\text { Total acid } \\
(\mathrm{g} / \mathrm{kg})\end{array}$ & $\begin{array}{c}\text { Total } \\
\text { polyphenol } \\
(\mathrm{mg} / \mathrm{kg})\end{array}$ \\
\hline Fourie et al., 1991 & Bosc & 13.6 & 49.9 & 30.9 & & & & \\
\hline Morvai \& Molnár-Perl 1992 & Bosc & 19.9 & 55 & 6.1 & 0.6 & 2.6 & & \\
\hline SOUCI et al, 2000 & not given & $15-16.9$ & $60.7-77$ & $12.4-25$ & 1.4 & 1.7 & & \\
\hline USDA database & not given & 27.6 & 62.3 & 7.8 & & & & \\
\hline fineli database & not given & 20 & 42 & 8 & & & 4 & \\
\hline \multirow{6}{*}{ Hudina et al., 2000} & Williams & 4.8 & 39.9 & 34 & 1.7 & 1.1 & & \\
\hline & Conference & 4.9 & 23.7 & 11.3 & 0 & 2.3 & & \\
\hline & Packham & 11.6 & 34.7 & 5.3 & 0.4 & 3.2 & & \\
\hline & Fétel & 16.3 & 43.6 & 6.6 & 0.4 & 3.2 & & \\
\hline & Bosc & 10.5 & 42.5 & 21.6 & 0.1 & 4.1 & & \\
\hline & Packham & 18.2 & 56.9 & 5.3 & & & & \\
\hline Yasunori \& Iki, 2002 & Williams & & & & & & & 167 \\
\hline Colaric et al., 2006 & Williams & 9.42 & 73.5 & 7.94 & $\max 3.05$ & $\max 2.24$ & & $447-616$ \\
\hline Colaric et al., 2007 & Conference & $7.63-14.75$ & $48.5-76$ & $6.6-18.53$ & $0.21-0.22$ & $1.97-4.25$ & & $162-231$ \\
\hline
\end{tabular}

humic soil. The pear orchard is cca 83 hectares, young plantation, planted in several phases $(1997,1999,2000$, 2001, and 2003). The biennial bearing characterizing pome fruits was present in 2008 to a small extent. The average crop yield was 37-45 kg in 2008 in fields planted in 1997-1999, $27-35 \mathrm{~kg}$ in fields planted in 2000-2001, while less than $5 \mathrm{~kg}$ in field planted in 2003.

'Bosc': planted in 1997, 1999, 2000, 2001, 2003, spacing $6 \times 3 \mathrm{~m}$ or $5 \times 3 \mathrm{~m}$ on a wild pear, (Pyrus pyraster), Farold $69-$ 87 or Pyrodwarf rootstock, Crown shape: free spindle. Produces few flowers, hardly drops any of them. Bosc exhibits a constant yield, fruits have always large size.

'Williams' pear: planted in 1997, 1999, 2000, 2001, 2003, spacing $6 \times 3 \mathrm{~m}$ or $5 \times 3 \mathrm{~m}$ on a wild pear, (Pyrus pyraster), Farold $69-87$ or Pyrodwarf rootstock, Crown shape: free spindle. It brings many flowers, covering almost the whole tree, but drops much of it. This cultivar is also able for regular production

'Packham's Triumph': planted in: 1997, 2000, 2001, Spacing: $6 \times 3 \mathrm{~m}$ or $5 \times 3 \mathrm{~m}$ on a wild pear (Pyrus pyraster), Farold 69-87 or Pyrodwarf rootstock. Crown shape: free spindle. One of parents is 'Williams' pear, so it has similar characteristics in flowering and bearing.

'Conference': planted in 1999. Spacing $5 \times 3 \mathrm{~m}$ on a Farold 69-87 rootstock, crown shape: free spindle. This cultivar is able to bring a high crop yield, but it is liable to biennial bearing. It is characterised by parthenocarp fruit production, often even the core is vestigial. In 2008 'Conference' brought nice large size fruits at Feketesár.

Storage: Gyümölcskert cPlc performs pear storage in its own ULO (Ultra low oxygen level) storage room. Pears were kept about three to four months in store. Controlled atmosphere values were as follows: $\mathrm{O}_{2}$ level: $3.0-5.0 \%, \mathrm{CO}_{2}$ level: $0.9-1.0 \%$, temperature: $-0.5-0.0{ }^{\circ} \mathrm{C}$

The free radical 1,1-diphenyl-2-picrylhydrazyl (DPPH) and standard Trolox, (6-hydroxy-2,5,7,8-tetramethylcromane-2-carboxylic acid) were obtained from Fluka (Buchs, Switzerland). Other reagents were of analytical grade and purchased from Reanal (Budapest, Hungary).

\section{Methods used}

Pear fruits were washed and then the size and weight of 50 fruits was measured according to Hungarian Standard MSZ 967-1:1982. From approximately five kg sample one $\mathrm{kg}$ optimally ripened, sound fruit was selected, core removed and disintegrated unpeeled using a Waring (Torrington, USA) blender. The blended fruit sample was used in the different measurements and chemical analyses.

Soluble solids, titratable acidity $(\mathrm{mg} / \mathrm{kg})$ total polyphenols $(\mathrm{mg} / \mathrm{kg}$ as gallic acid equivalent), free radical scavenging activity (TEAC: $\mathrm{mmol} / \mathrm{kg}$ ), copper and zinc $(\mathrm{mg} / \mathrm{kg}$ ) were measured as described previously (Tóth-Markus et al., 2010). Glucose, fructose and sucrose were determined enzymatically according to Hungarian standards MSZ EN 1140 and MSZ EN 12146. The water soluble pectin was measured from the five-fold diluted pear puree according to IFU 26. Calibration was performed with galacturonic acid. (Precision of the method within laboratory is approximately $10 \%$.)

The values from chemical analyses were fresh weightrelated and are given as means and standard deviation of triplicate samples. 
Table 2: Size and weight of pears

\begin{tabular}{|c|c|c|c|c|c|c|c|c|}
\hline Cultivar & Date & $\begin{array}{c}\text { Width avg. } \\
(\mathrm{cm})\end{array}$ & $\begin{array}{c}\text { Greatest } \\
\text { width }(\mathrm{cm})\end{array}$ & $\begin{array}{c}\text { Smallest } \\
\text { width }(\mathrm{cm})\end{array}$ & $\begin{array}{c}\text { Length } \\
\text { avg }(\mathrm{cm})\end{array}$ & $\begin{array}{c}\text { Greatest } \\
\text { length }(\mathrm{cm})\end{array}$ & $\begin{array}{c}\text { Smallest } \\
\text { length }(\mathrm{cm})\end{array}$ & $\begin{array}{c}\text { Avg. } \\
\text { weight (g) }\end{array}$ \\
\hline Williams & 01.08.2008. & 6.60 & 7.32 & 5.81 & 8.43 & 9.85 & 7.38 & 175 \\
\hline Bosc & 02.09.2008. & 7.31 & 8.68 & 6.53 & 10.51 & 11.95 & 8.52 & 258 \\
\hline Packham's Triumph & 03.09.2008. & 7.04 & 8.11 & 5.95 & 8.45 & 9.98 & 7.32 & 199 \\
\hline Conference & 30.08.2008. & 6.57 & 7.54 & 5.58 & 9.61 & 11.80 & 8.15 & 184 \\
\hline Abate Fétel & 02.09.2008. & 6.74 & 7.45 & 5.95 & 11.40 & 13.90 & 9.22 & 218 \\
\hline Williams & 01.09.2009. & 6.72 & 7.75 & 5.68 & 8.65 & 11.20 & 7.12 & 190 \\
\hline Bosc & 02.09.2009. & 7.50 & 8.62 & 5.95 & 12.19 & 13.55 & 10.03 & 275 \\
\hline Packham's Triumph & 01.10.2009. & 7.96 & 8.95 & 6.92 & 9.72 & 11.78 & 8.04 & 279 \\
\hline Conference & 01.10.2009. & 6.67 & 7.39 & 6.03 & 10.24 & 11.55 & 8.95 & 190 \\
\hline Abate Fétel & 01.10.2009. & 7.61 & 9.22 & 6.55 & 12.50 & 15.05 & 9.95 & 301 \\
\hline Williams & 12.08.2010. & 6.80 & 7.74 & 5.48 & 8.98 & 10.16 & 7.35 & 201 \\
\hline Bosc & 25.09.2010 & 7.14 & 8.19 & 6.06 & 9.62 & 11.08 & 8.35 & 213 \\
\hline Packham's Triumph & 25.09.2010. & 7.54 & 8.28 & 6.69 & 8.37 & 9.65 & 7.06 & 229 \\
\hline Conference & 25.09.2010. & 6.98 & 7.58 & 6.38 & 12.32 & 9.53 & 7.28 & 218 \\
\hline Abate Fétel & 25.09.2010. & 6.66 & 7.50 & 6.02 & 10.98 & 15.12 & 8.02 & 212 \\
\hline
\end{tabular}

\section{Results and discussion}

As it is well known that wheather has a strong influence on fruit properties, a short description is given on the weather conditions of years 2008-2009 at the orchard near Nagykanizsa.

2008.: It was a hot summer with poor precipitate, a +41$+42{ }^{\circ} \mathrm{C}$ peak temperature in July. High temperature tried trees, there were also sunburst fruits. There was a significant damage by Psylla pyri and sooty mould, grown on honeydew. The continuous irrigation raised the expenses. Crop yield was relevant to the age and condition of trees. Storage was finished in February. Loss on storage was minimal. This was the best year of the interval studied.

2009 started promising, a frost-free blooming and good fruit set. The time of fruit growths was rich in precipitation. Psylla infection was weak. Erwinia amylovora and Venturia caused minimal problem. Afterwards two hailstorms destroyed a significant part of crop. The harvested crop was partly damaged and there was a $7-10 \%$ loss in storage.

2010 is found to be an intermittent year. The fluctuating temperature at the end of winter and beginning of March shocked the trees. The greatest problem is the poor bud differentiation of the main cultivar 'Bosc'. The night chills influenced fruit set adversely, further deteriorating the chances of fruit growth. None of the other cultivars produced the expected crop yield. Only 'Packham' approximated the expectations in yield. Because of the extraordinarily rainy weather there was a minimal need for irrigation, but the weather favoured bacterial and fungal infections.

The size and weight values measured in three consecutive years with five cultivars are summarized as Table 2. The average weights per piece are generally lower than those given by Hudina and Štampar (2000). 'Williams' pear (Figure 1) had the lowest weight per piece in all the three crop years.

Table 3 shows the compositional characteristics of cultivars during storage. The changes in glucose, fructose and sucrose at harvest and after two and four months in ULO store can be seen on Figure 2. The water soluble solids (Brix), total sugar, sucrose and water soluble pectin were all decreasing during storage. This is not in agreement with the conclusion of work of Morvai and Molnár-Perl (1992), in

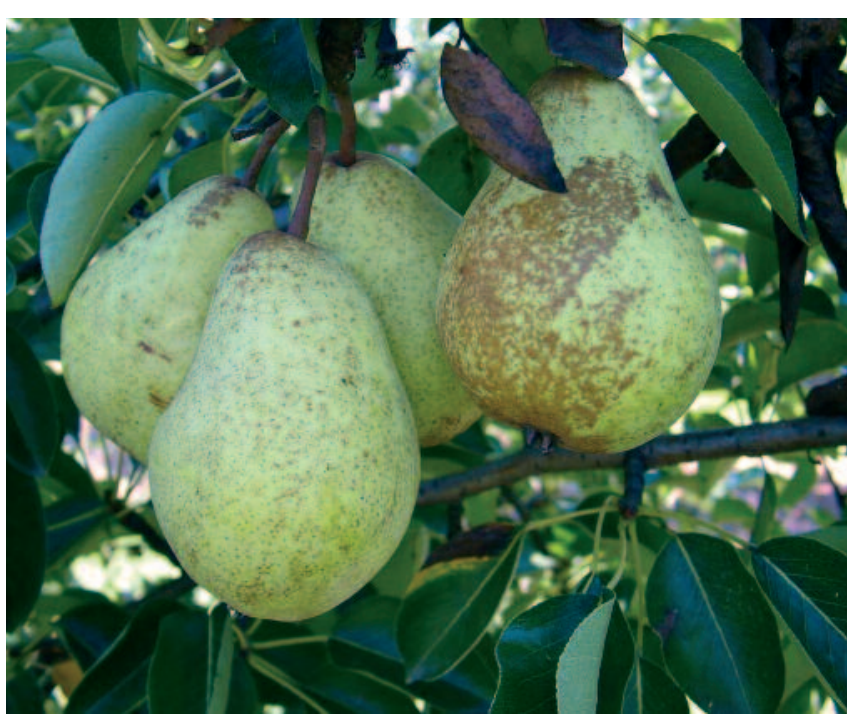

Figure 1: Williams pear at Nagykanizsa 
Table 3: Characteristics of pear during storage

\begin{tabular}{|c|c|c|c|c|c|c|c|c|c|}
\hline Cultivar & Date & Brix(degree) & $\begin{array}{l}\text { Titr acidity } \\
\mathrm{pH} 8.1 \mathrm{avg} \\
\text { (g/kg CA) }\end{array}$ & $\begin{array}{l}\text { Titr acidity } \\
\text { pH } 8.1 \text { std. } \\
\text { dev } \\
\text { (g/kg CA) }\end{array}$ & $\begin{array}{c}\text { Total poly- } \\
\text { phenol avg } \\
(\text { GAE } \mathrm{mg} / \mathrm{kg})\end{array}$ & $\begin{array}{c}\text { Total poly- } \\
\text { phenol std. } \\
\text { dev } \\
\text { (GAE mg/kg) }\end{array}$ & $\begin{array}{l}\text { TEAC avg } \\
(\mathrm{mmol} / \mathrm{kg})\end{array}$ & $\begin{array}{c}\text { TEAC std. } \\
\text { dev } \\
(\mathrm{mmol} / \mathrm{kg})\end{array}$ & $\begin{array}{l}\text { Water soluble } \\
\text { pectin }(\mathrm{g} / \mathrm{kg})\end{array}$ \\
\hline \multicolumn{10}{|c|}{ at harvest } \\
\hline Bosc & 02.09 .2008 & 16.1 & 1.38 & 0.15 & 143 & 88 & 1.4 & 0.1 & 1.49 \\
\hline Packham's Triumph & 03.09.2008. & 14.8 & 1.48 & 0.08 & 468 & 4 & 2.2 & 0.1 & 1.93 \\
\hline Conference & 30.08 .2008 & 17.4 & 1.26 & 0.13 & 120 & 24 & 1.5 & 0.2 & 2.06 \\
\hline Abate Fétel & 02.09.2008. & 15 & 1.44 & 0.18 & 676 & 5 & 4.8 & 0.2 & 1.56 \\
\hline \multicolumn{10}{|c|}{ taken from store at 10th November, 2008} \\
\hline Bosc & 02.09.2008. & 15.2 & 1.49 & 0.08 & 178 & 22 & 1.7 & 0 & 1.57 \\
\hline Packham's Triumph & 03.09.2008. & 14 & 1.49 & 0.01 & 411 & 22 & 2.6 & 0.1 & 1.57 \\
\hline Conference & 30.08 .2008 & 16.9 & 1.41 & 0.03 & 134 & 5 & 1.2 & 0.1 & 1.13 \\
\hline Abate Fétel & 02.09.2008. & 14.8 & 1.8 & 0.02 & 836 & 9 & 5.3 & 0.2 & 1.2 \\
\hline \multicolumn{10}{|c|}{ taken from store at 12th January, 2009} \\
\hline Bosc & 02.09.2008. & 14.3 & 1.63 & 0.05 & 251 & 3 & 1.2 & 0.0 & 1.23 \\
\hline Packham's Triumph & 03.09.2008. & 12.9 & 1.45 & 0.03 & 516 & 4 & 2.6 & 0.5 & 0.6 \\
\hline Conference & 30.08 .2008 & 16.9 & 1.13 & 0.02 & 234 & 26 & 1.0 & 0.0 & 0.7 \\
\hline Abate Fétel & 02.09.2008. & 14.2 & 1.48 & 0.03 & 805 & 69 & 5.1 & 0.1 & 0.67 \\
\hline
\end{tabular}

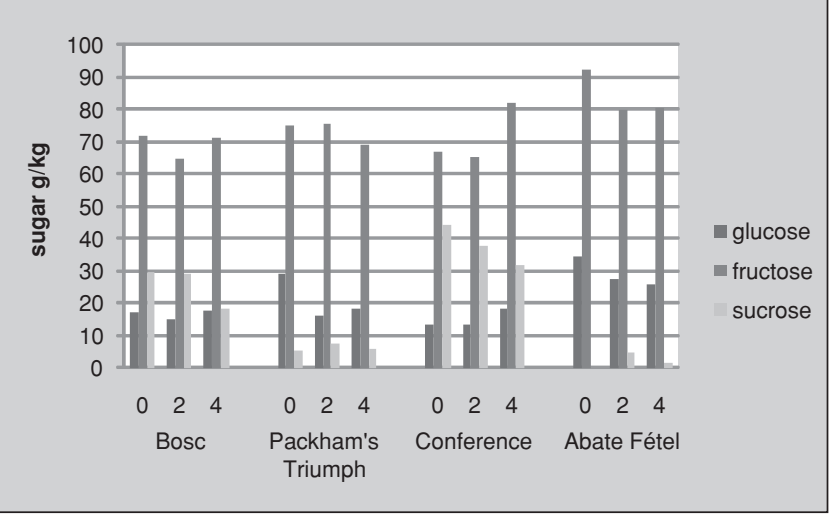

Figure 2: Change in sugar components during 4 months storage

which storage conditions were not described: Decline of water content could lead to a virtual increase of sugars and acids. According to our study, titratable acidity remained practically constant, except that slight decrease was observed in fruits of the cultivar Conference. Polyphenols and free radical scavenging capacity did not show a significant change during four months storage.

As comparing the composition of pear cultivars in three consecutive years, (Table 4 and Figure 3), 'Conference' and 'Bosc' contained the highest sucrose level, while 'Williams' pear was found to contain the highest acidity among the cultivars tested. 'Conference' had the highest total sugar content, while 'Abate Fétel' had the lowest sucrose and highest glucose of the cultivars tested. The high sucrose content is interesting, as the AIJN Code of Practice gives an upper limit of $15 \mathrm{~g} / \mathrm{kg}$ for $100 \%$ pear puree. All the sugars measured by our team are much higher (often double) than the values of Hudina and Štampar (2000) found in Slovenian grown fruits.

The content of water soluble pectin present in pears changed from 0.43 ('Williams' 2009) to $2.06 \mathrm{~g} / \mathrm{kg}$ ('Conference', 2008).

Total polyphenol content and free radical scavenging activity was excellent in 'Abate Fètel' variety, followed by 'Packham's Triumph', the maximum total phenol is 836 $\mathrm{mg} / \mathrm{kg}$ fresh weight. The measured polyphenol content is a bit less than the results of Leontowicz et al. (2002), who found about $2 \mathrm{~g} / \mathrm{kg}$ for peeled pear and about $4 \mathrm{~g} / \mathrm{kg}$ for peel.

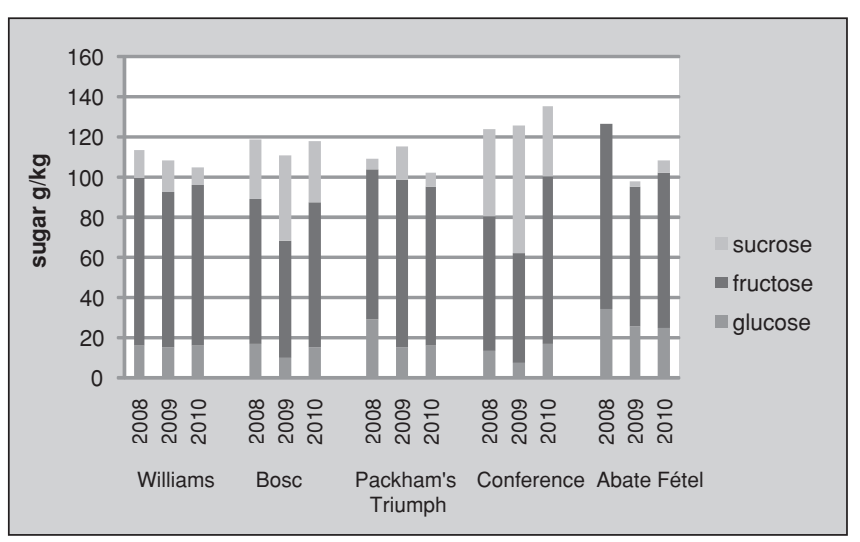

Figure 3: Main sugars of pears 2008-2010 
Table 4: Characteristics of pear cultivars in 2008-2010 period

\begin{tabular}{|c|c|c|c|c|c|c|c|c|c|}
\hline Cultivar & Date & Brix(degree) & $\begin{array}{c}\text { Titr acidity } \mathrm{pH} \\
8.1 \mathrm{avg}(\mathrm{g} / \mathrm{kg} \\
\mathrm{CA})\end{array}$ & $\begin{array}{c}\text { Titr acidity pH } \\
8.1 \mathrm{std} . \mathrm{dev} \\
(\mathrm{g} / \mathrm{kg} \mathrm{CA})\end{array}$ & $\begin{array}{c}\text { Total poly- } \\
\text { phenol avg } \\
\text { (GAE } \mathrm{mg} / \mathrm{kg} \text { ) }\end{array}$ & $\begin{array}{l}\text { Total poly- } \\
\text { phenol std. } \\
\text { dev (GAE } \\
\text { mg/kg) }\end{array}$ & $\begin{array}{l}\text { TEAC avg } \\
(\mathrm{mmol} / \mathrm{kg})\end{array}$ & $\begin{array}{c}\text { TEAC std. dev } \\
(\mathrm{mmol} / \mathrm{kg})\end{array}$ & $\begin{array}{l}\text { Water soluble } \\
\text { pectin }(\mathrm{g} / \mathrm{kg})\end{array}$ \\
\hline Williams & 01.08.2008. & 14.9 & 1.85 & 0.11 & 215 & 48 & 1.8 & 0 & 1.7 \\
\hline Bosc & 02.09.2008. & 16.1 & 1.38 & 0.15 & 143 & 88 & 1.4 & 0.1 & 1.49 \\
\hline Packham's Triumph & 03.09.2008. & 14.8 & 1.48 & 0.08 & 468 & 4 & 2.2 & 0.1 & 1.93 \\
\hline Conference & 30.08.2008. & 17.4 & 1.26 & 0.13 & 120 & 24 & 1.5 & 0.2 & 2.06 \\
\hline Abate Fétel & 02.09 .2008 & 15 & 1.44 & 0.18 & 676 & 5 & 4.8 & 0.2 & 1.56 \\
\hline Williams & 01.09.2009. & 15.3 & 3.34 & 0.06 & 383 & 15 & 1.8 & 0.1 & 0.433 \\
\hline Bosc & 02.09 .2009 & 14.3 & 1.34 & 0.1 & 391 & 67 & 1.6 & 0.1 & 1.777 \\
\hline Packham's Triumph & 01.10.2009. & 15 & 1.67 & 0 & 836 & 43 & 4.5 & 0 & 0.524 \\
\hline Conference & 01.10.2009. & 15 & 1.1 & 0.16 & 522 & 56 & 2.4 & 0.1 & 0.779 \\
\hline Abate Fétel & 01.10.2009. & 13.8 & 2.01 & 0.1 & 830 & 48 & 4.2 & 0.2 & 0.757 \\
\hline Williams & 12.08 .2010 & 13.1 & 2.52 & 0.02 & 346 & 40 & 2 & 0.1 & 1.147 \\
\hline Bosc & 25.09.2010 & 15.4 & 2.27 & 0.03 & 322 & 9 & 2.3 & 0 & 1.013 \\
\hline Packham's Triumph & 25.09.2010. & 13.2 & 1.29 & 0.08 & 396 & 17 & 2.8 & 0 & 0.792 \\
\hline Conference & 25.09.2010 & 15.9 & 1.63 & 0 & 200 & 12 & 1.2 & 0 & 1.01 \\
\hline Abate Fétel & 25.09.2010 & 13.5 & 2.08 & 0.05 & 698 & 18 & 4.6 & 0.1 & 1.11 \\
\hline
\end{tabular}

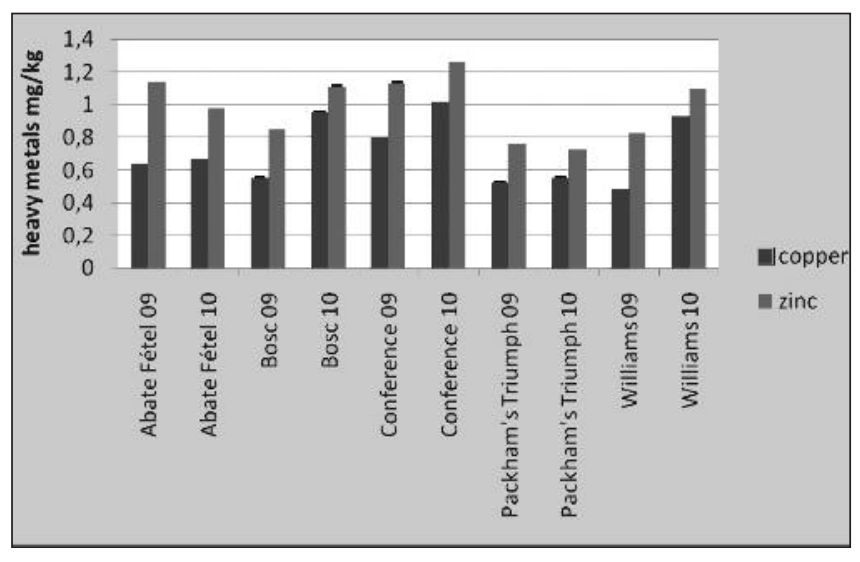

Figure 4: Copper and zinc content in pears 2009-2010

Our value is similar to the sum of phenolic compounds found by Colaric et al. (2006) in 'Williams' pear (44,7-61,6 $\mathrm{mg} / 100 \mathrm{~g})$. Yasunori and Iki (2002) report 16,7 mg polyphenol/100 $\mathrm{g}$ fresh weight also in Williams pear. They detected a slight temporary increase of polyphenols in the first two weeks of storage, and a decline to the starting value at about two months of storage. Alvarez-Fernandez et al (2011), stated a value range of $0.62-0.74 \mathrm{mg} / 100 \mathrm{~g}$ fresh weight values for total phenols in Blanquilla pears.

Comparing the copper and zinc content of pears in two consecutive years (Figure 4), zinc was always higher. Copper in 2010 was higher in all cultivars than in 2009. Both heavy metals are well under the AIJN Code of Practice limit $(5 \mathrm{mg} / \mathrm{kg})$

\section{Acknowledgements}

This work was financed by NFÜ TECH_08-A3/2-20080373 grant.

\section{References}

Álvarez-Fernández A, Melgar JC, Abadía J \& Abadía A (2011): Effects of moderate and severe iron deficiency chlorosis on fruit yield, appearance and composition in pear (Pyrus communis L.) and peach (Prunus persica (L.) Batsch). Environmental and Experimental Botany, 71: 280-286.

Association of the Industry of Juices and Nectars from Fruits and Vegetables of the European Union (A.I.J.N.) (2005): Code of Practice for evaluation of fruit and vegetable juices 6-8-reference guideline for pear

Colaric M, Štampar F, Solar A \& Hudina M (2006): Influence of branch bending on sugar, organic acid and phenolic content in fruits of 'Williams' pears (Pyrus communis L.) Journal of the Science of Food and Agriculture, 86: 2463-2467.

Colaric M, Štampar F \& Hudina M (2007): Content levels of various fruit metabolites in the 'Conference' pear response to branch bending. Scientia Horticulturae, 113: 261-266.

Elgar HJ, Watkins CB, Murray SH \& Gunson FA (1997): Quality of 'Beurre Bosc' and 'Doyenne du Comice' pears in relation to harvest date and storage period. Postharvest Biology and Technology, 10: 29-37.

Fourie PC, Hanmann CF \& Oberholzer HM (1991): Sugar content of fresh apples and pears in South Africa. Journal of Agricultural and Food Chemistry, 39: 1938-1939. 
http://www.fineli.fi/food.php?foodid=28917\&lang=en (2011.02.22)

http://www.nal.usda.gov/fnic/foodcomp/cgi-bin/list_nut_edit.pl (2011.02.22)

Hudina M \& Štampar F (2000): Sugars and organic acids contents of European (Pyrus communis L.) and Asian (Pyrus serotina REHD.) pear cultivars. Acta Alimentaria, 29 (3): 217-230.

\section{IFU 26 (1995): Pectin}

Leontowicz H, Gorinstein S, Lojek A, Leontowicz M, Číž M, Soliva-Fortuny R, Park YS, Jung ST, Trakhtenberg S \& Martin-Belloso O (2002): Comparative content of some bioactive compounds in apples, peaches and pears and their influence on lipids and antioxidant capacity in rats. Journal of Nutritional Biochemistry, 13: 603-610.

Morvai M \& Molnar-Perl. I (1992): Simultaneous gas chromatographic quantitation of sugars and acids in citrus fruits, pears, bananas, grapes, apples and tomatoes. Chromatographia, 34 (9-10): 502-504.

MSZ EN 1140-2:1995 Fruit and vegetable juices. Enzymatic determination of D-glucose and D-fructose content. NADPH spectrometric method

MSZ EN 12146:1998 Fruit and vegetable juices. Enzymatic determination of sucrose content. NADPH spectrometric method

Souci SW, Fachmann W \& Kraut H (2000): Food composition and nutrition tables, $6^{\text {th }}$.ed., Medpharm Scientific Publishers Stuttgart, CRC press, Boca Raton, London, New York, Washington, D.C., 1030-1031.

Yasunori H. \& Iki S (2002): Changes in polyphenolic compounds and antioxidant functions in 'Bartlett" pear fruit during storage and postharvest ripening. Food Preservation Science, 28 (1): 25-32. 